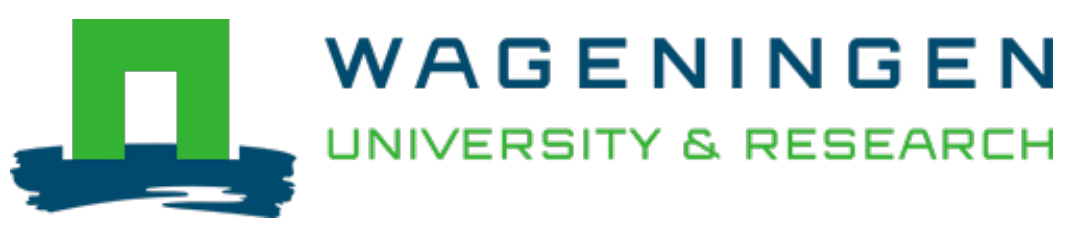

\title{
Occurrence of Aspergillus section Flavi and section Nigri and aflatoxins in raw cashew kernels (Anacardiumoccidentale L.) from Benin
}

Food Science and Technology = Lebensmittel-Wissenschaft und Technologie

Lamboni, Y.; Frisvad, J.C.; Hell, K.; Linnemann, A.R.; Nout, M.J.R. et al

https://doi.org/10.1016/j.lwt.2016.02.017

This publication is made publicly available in the institutional repository of Wageningen University and Research, under the terms of article $25 \mathrm{fa}$ of the Dutch Copyright Act, also known as the Amendment Taverne. This has been done with explicit consent by the author.

Article 25 fa states that the author of a short scientific work funded either wholly or partially by Dutch public funds is entitled to make that work publicly available for no consideration following a reasonable period of time after the work was first published, provided that clear reference is made to the source of the first publication of the work.

This publication is distributed under The Association of Universities in the Netherlands (VSNU) 'Article $25 \mathrm{fa}$ implementation' project. In this project research outputs of researchers employed by Dutch Universities that comply with the legal requirements of Article $25 \mathrm{fa}$ of the Dutch Copyright Act are distributed online and free of cost or other barriers in institutional repositories. Research outputs are distributed six months after their first online publication in the original published version and with proper attribution to the source of the original publication.

You are permitted to download and use the publication for personal purposes. All rights remain with the author(s) and / or copyright owner(s) of this work. Any use of the publication or parts of it other than authorised under article $25 \mathrm{fa}$ of the Dutch Copyright act is prohibited. Wageningen University \& Research and the author(s) of this publication shall not be held responsible or liable for any damages resulting from your (re)use of this publication.

For questions regarding the public availability of this publication please contact openscience.library@wur.nl 


\title{
Occurrence of Aspergillus section Flavi and section Nigri and aflatoxins in raw cashew kernels (Anacardiumoccidentale L.) from Benin
}

\author{
Yendouban Lamboni a, b, c, d, Jens C. Frisvad ${ }^{\text {b }}$, Kerstin Hell a , Anita R. Linnemann ${ }^{\text {c }}$, \\ Rob M.J. Nout ${ }^{\mathrm{d}}$, Manuele Tamo ${ }^{\mathrm{a}}$, Kristian F. Nielsen ${ }^{\mathrm{b}}$, Martinus A.J.S. van Boekel ${ }^{\mathrm{c}}$, \\ Eddy J. Smid d, * \\ a International Institute of Tropical Agriculture, 08 BP 0932 Tri postal, Cotonou, Benin \\ b Department of Systems Biology, Technical University of Denmark, Building 221, DK-2800 Kgs, Lyngby, Denmark \\ c Food Quality and Design Group, Wageningen University, P.O. Box 17, 6700AA, Wageningen, The Netherlands \\ d Laboratory of Food Microbiology, Wageningen University, P.O. Box 17, 6700AA, Wageningen, The Netherlands
}

\section{A R T I C L E I N F O}

\section{Article history:}

Received 13 November 2015

Received in revised form

15 January 2016

Accepted 7 February 2016

Available online 11 February 2016

\section{Keywords:}

Aspergillus section Flavi

Aspergillus section Nigri

Aflatoxins

Cashew nuts

Benin

\begin{abstract}
A B S T R A C T
The objective of this study was to evaluate the presence of Aspergillus section Flavi and A. section Nigri in cashew nuts harvested in the Northern Guinea (NG) and Southern Sudanian (SS) agro-ecological zones of Benin. Also, the presence of aflatoxins was investigated. For detection of fungal contamination, a total of 100 kernels/sample (with disinfection) and 40 kernels/sample (without disinfection) were plated. Seventy samples from fourteen villages were used. Aflatoxins occurrence was analysed on 84 samples by ultra-high performance liquid chromatography tandem mass spectrometry (UHPLC-MS/MS). The average water content and the cashew nuts count were respectively $8.6 \%$ and 172 nuts/ $\mathrm{kg}$ in NG and $8.7 \%$ and 174 nuts $/ \mathrm{kg}$ in SS. Significant differences between villages in both zones were found for both water content and nuts count. In disinfected samples, strains of Aspergillus section Nigri were predominant, in NG and SS zones (90.2\% and 87.2\%) respectively. When non disinfected kernels were plated, $A$. section Nigri was predominant in both NG and SS zones, with percentages of $89.7 \%$ and $93.4 \%$, respectively. None of the 84 nuts samples were positive for natural occurrence of aflatoxins with a detection limit of 0.05 $-0.2 \mu \mathrm{g} / \mathrm{kg}$.
\end{abstract}

๑) 2016 Elsevier Ltd. All rights reserved.

\section{Introduction}

The cashew (Anacardium occidentale L., Anacardiaceae) originates from north-eastern Brazil and was introduced, in the sixteenth century, in other tropical regions of the world. Its edible part is one of the major agricultural export crops in Benin. In Benin, in 2012 cashew nut trees were cultivated on about 468.000 ha. The average production over the last 5 years was approximately 128 tons per year. In 2011, the annual turn-over for cashew exports was estimated at 150 million US dollars (FAOSTAT, 2015). Beninese cashew nuts account for $8 \%$ of national export revenues and $25 \%$ of agricultural export revenues (ACi, 2010).

Nuts are susceptible to fungal growth according to their intrinsic characteristics of water activity, moisture content, nutrient

\footnotetext{
* Corresponding author. Tel.: +31317482834

E-mail address: eddy.smid@wur.nl (E.J. Smid).
}

composition and pH which favour the growth of fungi (Tolosa, Font, Manes, \& Ferrer, 2013). According to Milhome et al. (2014), cashew nuts are subject to pre and post-harvest fungal contamination facilitating the production of mycotoxins.

Mycotoxins are secondary metabolites produced by certain type of filamentous fungi. Aspergillus is one of the most important genera including section Flavi with more than twenty species (Varga, Frisvad, \& Samson, 2011). The predominant fungi reported on cashew nuts are Aspergillus niger, A. flavus, Mucor spp. and Rhizopus spp (Adebajo \& Diyaolu, 2003; Freire, Kozakiewicz, \& Paterson, 1999). with A. flavus and A. parasiticus being the main producers of aflatoxins.

Around 20 chemically related compounds are called by the term aflatoxins in which the most important are $A_{1} B_{1}, A f B_{2}, A f G_{1}$ and $\mathrm{AfG}_{2}$. $\mathrm{AfB}_{1}$ is the most toxic variant and has been classified by the International Agency for Research on Cancer as a group 1 carcinogen primarily affecting the liver (IARC, 1993). The European commission's regulations set limits for $\mathrm{AfB}_{1}$ and total aflatoxins of 5 
and $10 \mu \mathrm{g} / \mathrm{kg}$, respectively, for cashew nuts to be subject to sorting or other physical treatment, and of 2 and $4 \mu \mathrm{g} / \mathrm{kg}$ respectively, for processed nuts intended for direct human consumption (European Commission, 2010).

Several authors have reported the presence of mycotoxigenic fungi on cashew nuts and cashew products (Abdulla, 2013; Freire et al., 1999; Lawal \& Fagbohun, 2014). Detectable levels of aflatoxins on processed cashew nuts were reported in several countries including Venezuela (Acevedo, Smith, Ana, \& Villarroel, 2011), Iraq (Abdulla, 2013) and Brazil (Milhome et al., 2014) but on raw cashew nuts, there is few data about natural occurrence of aflatoxins.

The aim of this study is to evaluate the occurrence of Aspergillus section Flavi and $A$. section Nigri on raw cashew nuts from northern Benin, and to investigate the presence of aflatoxins in these kernels. This is also the first report to describe the incidence of fungal contamination and presence of aflatoxins in raw cashew kernels from Benin.

\section{Materials and methods}

\subsection{Sampling area-geographic and climatic characterization}

Cashew nuts were sampled in production areas covering two agro-ecological zones of Benin in 2013: Northern Guinea (NG) and Southern Sudanian (SS). NG lies within latitudes $8^{\circ} 1^{\prime}$ and $10^{\circ} 6^{\prime} \mathrm{N}$ whereas SS lies within latitudes $9^{\circ} 4^{\prime}$ and $12^{\circ} 3^{\prime} \mathrm{N}$. NG and SS are covered by a unimodal rainfall distribution averaging $1000 \mathrm{~mm}$ annually, and maximum temperatures varying from $28^{\circ} \mathrm{C}$ to $40^{\circ} \mathrm{C}$.

Fourteen villages were selected for sampling: Alafiarou, Bante, Ina, Kilibo, Tchaourou, Tchatchou and Toui (in NG) and Birni, Chabikouma, Kolokonde, Nagayile, Patargo, Penessoulou and Pira (in SS). These villages were selected based on their accessibility (Fig. 1).

\subsection{Sampling procedure}

Sampling was done according to Whitaker, Slate, Doko, Maestroni, and Cannavan (2010) and the European Regulation (EC No. 401/2006) describing the methods of sampling and analysis for the official control of the levels of mycotoxins in foodstuffs for small lots. In each village, ten farmers, with cashew farm's area of 5 ha or more, were identified, and harvested cashew nuts were sampled. Polyethylene bags, jute bags, plastic or metal basins and in piles on the ground, are the most common storage systems used in the study area. The available nuts, were thoroughly mixed and 10 different incremental samples were taken to approximately $3 \mathrm{~kg}$ from each farmer. The samples were then labelled, placed in paper bags and transported within the next 3 days to the laboratory. A total of 140 samples were collected. To prevent postharvest changes, samples were stored at $4{ }^{\circ} \mathrm{C}$ for further analysis except sub-samples for water content analysis.

\subsection{Cashew kernels extraction}

The water content, microbial contamination and the aflatoxins content were evaluated on cashew kernels. From each nut, the shell was cut in two pieces, using a sharp scalpel and the two cotyledons were extracted. The extraction was done under aseptic conditions. Cross contamination was prevented by disinfecting the scalpels with $90 \%$ ethanol. The extracted kernels were put in plastic bags and kept in a refrigerator at $4{ }^{\circ} \mathrm{C}$ for further analysis.

\subsection{Evaluation of nuts count and water content}

The count is defined as the number of nuts per kilogram (ACi, 2012). Evaluation was done by mixing each sample and counting
3 replicates of $1 \mathrm{~kg}$.

The water content was determined using the oven-drying method prescribed by ISO 665-2000 (UNECE, 2002). In duplicate, $10 \mathrm{~g} \pm 1 \mathrm{mg}$ of crushed kernels were placed in a metal box, dried at $103 \pm 2{ }^{\circ} \mathrm{C}$ for $6 \mathrm{~h}$ at atmospheric pressure, with further drying for $3 \mathrm{~h}$ until constant mass was reached. The mean water content was calculated and expressed as percentage on wet weight basis.

\subsection{Mycobiota isolation and identification}

\subsubsection{Culture media}

For mycobiota isolation, several media were used: Dichloran $18 \%$ glycerol agar (DG18, Oxoid) (Pitt \& Hocking, 1997) for growth of spores present on cashew kernels; Czapek yeast autolysate (CYA) agar (Frisvad \& Samson, 2004), Malt extract agar (MEA, Oxoid) (Samson, Houbraken, Kuijpers, Frank, \& Frisvad, 2004), and Yeast extract sucrose agar (YES) (Pitt \& Hocking, 1997) for isolation, morphological observation and identification.

\subsubsection{Surface disinfection plating}

Seventy samples were used for surface disinfection. In order to evaluate the presence of fungi on 100 cotyledons per village, 5 replicates of 4 cotyledons from 5 subsamples per village were randomly picked and surface sterilized for $2 \mathrm{~min}$ in $0.4 \%$ aqueous solution of sodium hypochlorite, followed by three subsequent rinsings of 2 min with sterile ultrapure water (Millipore Synergy ${ }^{\circledR}$ $U V$, Molsheim, France). With sterile forceps, the cotyledons were plated together equi-spaced from each on DG18; two of the cotyledons having their inner surface turned up and the remaining two having their outer surface turned up (Suppl. Fig. 1) according to Adebajo \& Diyaolu (2003). Plates were incubated in perforated plastic bags at $25{ }^{\circ} \mathrm{C}$ in the dark for 7 days. After the incubation period, the number of cotyledons on which fungal growth was noticed and which showed morphologies consistent with Aspergillus section Flavi and A. section Nigri, were counted separately. These strains were isolated and inoculated at three points equidistant from the centre on CYA, MEA and YES and incubated at $25{ }^{\circ} \mathrm{C}$ in the dark for 7 days for morphological observation and identification. The strains identified in Aspergillus Section Flavi were A. flavus, A. tamari, A. costaricaensis, A. minisclerotigenes and $A$. nomius. Other species belonging to Eurotium and Rhizopus and Mucor were also recorded.

\subsubsection{Non-disinfection plating}

The above mentioned plating method was used for direct plating of cashew cotyledons on DG18 without any surface disinfection. A total of 40 cotyledons ( 2 replicates of 4 from 5 subsamples per village) were plated and all the strains belonging to Aspergillus section Flavi and $A$. section Nigri were transferred to CYA, MEA and YES for identification.

Colony morphology, spore characteristics, mycelium growth, reverse plate observation and microscopic mounts were used for the identification of the strains according to taxonomic schemes and illustrations in Pitt and Hocking (2009), Samson, Hoekstra, Frisvad, and Filtenborg (2002; 2007; 2014) and Varga et al. (2011).

\subsection{Statistical analysis}

Simple descriptive analysis was used to evaluate the occurrence and the percentage of fungi. The frequencies of fungi occurrence were calculated as a percentage of cotyledons contaminated. Oneway ANOVA followed by Tukey HSD test $(p \leq 005)$ was used to separate average means of water content and nuts counts. T-test was used to separate means across the two agro-ecological zones. In the case there was significant difference between infection 


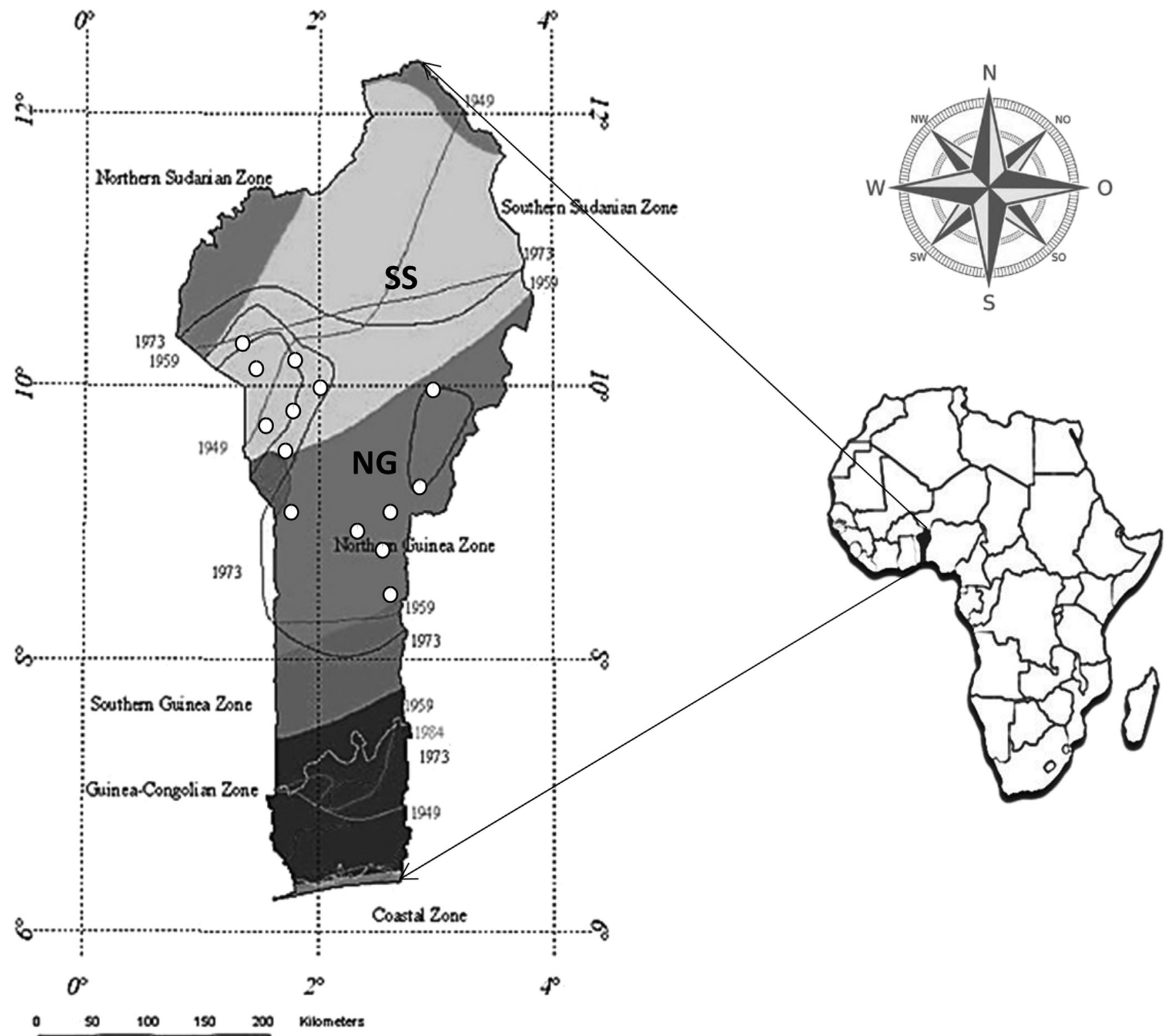

Fig. 1. Location of the sampling areas in two agro-ecological zones of Republic of Benin. $\square \mathrm{NG}=$ Northern Guinea.

$\square$ SS = Southern Sudanian (Map modified from Wezel, Bohlinger, \& Bocker, 1999).

percentage of fungi within villages, Bonferroni and Holm multiple comparison test was used to separate means.

\subsection{Aflatoxin extraction and quantification}

Certified mixed aflatoxins standards with a concentration of $2.0 \mathrm{ng} / \mu \mathrm{l}$ for $\mathrm{AfB}_{1}, 2.01 \mathrm{ng} / \mu \mathrm{l}$ for $\mathrm{AfB}_{2}$ and $0.5 \mathrm{ng} / \mu \mathrm{l}$ for $\mathrm{AfG}_{1}$ and $\mathrm{AfG}_{2}$, purchased from Biopure, (Tulln, Austria), were used for quantification. Stock solutions were prepared in methanol and kept at $-20{ }^{\circ} \mathrm{C}$. All solvents used for chemical analysis were LC-MS grade. Methanol, formic acid and acetonitrile were purchased from Sigma Aldrich (Denmark).

Raw cashew kernels were analysed for determination of the concentration of $\mathrm{AfB}_{1}, \mathrm{AfB}_{2}, \mathrm{AfG}_{1}$ and $\mathrm{AfG}_{2}$. In duplicate, 3 subsamples from the 14 villages were analysed, giving in total 84 samples. From each sample, $25 \mathrm{~g}$ of kernels were crushed until the size of particles obtained was no greater than $3 \mathrm{~mm}$. Next, $5 \mathrm{ml}$ of an acetonitrile:water $(85: 15, \mathrm{v} / \mathrm{v})$ mixture was added to $1 \mathrm{~g}$ of ground cashew kernels and extracted for 90 min using a GLF rotary shaker (Microlab, Aarhus). Samples were then centrifuged for $5 \mathrm{~min}$ at a speed of $4900 \mathrm{rpm}$. The extracts $(80 \mu \mathrm{l}+20 \mu \mathrm{l}$ of internal standard) were then transferred into glass vials and analysed by LCMS/MS without any further treatment. The internal standard used was ${ }^{13} \mathrm{C}$ labelled $\mathrm{AfB}_{1}$.

The analyses were performed using an UHPLC-MS/MS on an Agilent 1290 Infinity UHPLC with auto-sampler system coupled to an Agilent 6490 iFunnel Triple quadrupole MS (Agilent Technologies, Santa Clara, CA, Denmark) equipped with electrospray ionization (ESI) source (Nielsen, Ngemela, Jensen, de Medeiros, \& Rasmussen, 2015) operating in both negative and positive ionization modes. The injection volume was $2 \mu$ l. Separation was performed by using an Agilent Poroshell 120 Phenyl Hexyl column 
$(2.7 \mu \mathrm{m}, 100 \times 2.1 \mathrm{~mm})$ operating at $40{ }^{\circ} \mathrm{C}$ and a flow of 0.4

Linearity, limit of detection (LOD) and limit of quantification (LOQ) were determined to test the validity of the HPLC method used. Linearity was estimated by construction of a five-point calibration curve using Aflatoxins standards of $1-50 \mu \mathrm{g} / \mathrm{kg}$ of each aflatoxin. The recovery was ascertained by spiking $2 \mu \mathrm{g} / \mathrm{kg}$ of $\mathrm{AfB}_{1}$ and $\mathrm{AfG}_{1}$, and $1 \mu \mathrm{g} / \mathrm{kg}$ of $\mathrm{AfB}_{2}$ and $\mathrm{AfG}_{2}$ to the clean cashew nut powder. The recoveries ranged from $84.2 \%$ to $102.9 \%$. LOD and LOQ were determined in spiked sample as 3 and 10 times the standard deviation of the response over the slope of the calibration curve, respectively (Nielsen et al., 2015).

\section{Results}

\subsection{Cashew nuts count and water content of cashew kernels}

In NG, the average cashew nuts count ranged from 160 nuts $/ \mathrm{kg}$ (Kilibo) to 185 nuts/kg (Bante) with a mean value of 172 nuts/kg whereas in SS it ranged from 152 nuts $/ \mathrm{kg}$ (Pira) to 189 nuts $/ \mathrm{kg}$ (Chabi-Kouma) with mean value of 174 nuts/kg (Table 1). Significant differences were noticed between the average nuts counts in both NG and SS with p-values of 0.0008 and 0.0002 , respectively. The average nuts count within the country was 171 nuts $/ \mathrm{kg}$.

The average water content ranged from $5.7 \%$ (Ina) to $10.8 \%$ (Kilibo) in NG, with a mean value of $8.6 \%$. In SS, it ranged from $6.3 \%$ (Penessoulou) to $10.3 \%$ (Patargo), with mean value of $8.7 \%$ (Table 1 ). There were significant differences between the average water contents both in NG and SS ( $\mathrm{p}=0.0002 ; 0.0176)$. The average water content within the country was $8.6 \%$.

\subsection{Occurrence and distribution of fungi}

\subsubsection{Surface disinfected samples}

Using disinfected kernels, 14 and 17 of the 35 samples from respectively NG and SS contained strains of $A$. section Flavi (Table 2). The range of incidence of contamination varied in NG from 2.0 to $20.5 \%$ with mean value of $6.7 \%$ whereas it varied in SS from 0.5 to $9.5 \%$ with mean of $4.6 \%$. Strains of $A$. section Nigri were noticed in all 35 samples in both zones. In NG the incidence of $A$. section Nigri varied from 82.5 to $96.0 \%$ with the mean of $90.2 \%$. The range and the mean in SS were $70.5-98.5 \%$ and $87.2 \%$, respectively (Table 2).
In both NG and SS, strains of $A$. section Nigri were the most commonly isolated followed by Eurotium, A. section Flavi, Rhizopus and Mucor (Table 2). The total number of strains isolated varied from 43 to 66 and from 47 to 70 in NG and SS, respectively. In NG, the highest contamination level of $A$. section Flavi was noticed in Bante (20.5\%), whereas strains of $A$. section Nigri were homogeneously distributed across all locations. In SS, the highest contamination level of $A$. section Flavi was noticed in Penessoulou (9.5\%) together with the lowest contamination level of $A$. section Nigri (70.5\%). In SS, there was a significant difference between the contamination levels by strains of both $A$. section Flavi and $A$. section Nigri ( $\mathrm{p}=0.0281 ; \mathrm{p}=0.0011)$ (Table 2).

\subsubsection{Non-disinfected samples}

Two replications of 5 subsamples from the 14 locations were directly plated on culture media. Eleven and 19 of the 35 samples from respectively NG and SS contained strains of $A$. section Flavi (Table 3). The range of incidence of contamination varied from 1.3 to $32.5 \%$ in NG, with mean value of $10.0 \%$, whereas it varied in SS from 0 to $35 \%$ with mean of $15.7 \%$. All the samples from both zones were contaminated with $A$. section Nigri. The incidence of contamination varied from 75 to $98.8 \%$ (mean of $89.7 \%$ ) and $83.8-100 \%$ (mean of $93.7 \%$ ) in NG in SS, respectively (Table 3).

Aspergillus species belonging to section Nigri were isolated in all locations in both the NG and the SS zones and they were the most commonly occurring species (Table 3). They were followed by Eurotium, Rhizopus, A. section Flavi and Mucor. The number of strains isolated varied from 18 to 31 and 21 to 33 in both NG and SS, respectively. The same trend as on surface disinfected samples was noticed for the highest contaminated location in NG, being Bante (32.5\%). In SS, the highest contamination level of $A$. section Flavi was recorded in Penessoulou (35.0\%) with the lowest contamination of $A$. section Nigri (83.75\%). There was a significant difference ( $\mathrm{p}=0.0255$ ) between levels of contamination of $A$. section Flavi in NG. In SS, significant differences were noticed between of contamination levels by both $A$. section Flavi and $A$. section Nigri $(\mathrm{p}=0.0238 ; \mathrm{p}=0.0090)$ (Table 3$)$.

\subsection{Aflatoxins in cashew nuts}

The aflatoxin content was investigated using UHPLC-MS/MS. For $\mathrm{AfB}_{1}, \mathrm{AfB}_{2}, \mathrm{AfG}_{1}$ and $\mathrm{AfG}_{2}$, LOD were $0.2,0.2,0.05$ and $0.3 \mu \mathrm{g} / \mathrm{kg}$

Table 1

Averages nut count and water content of cashew nuts from sampling sites in Northern Guinea (NG) and Southern Sudanian (SS) agro-ecological zones of Benin in 2013.

\begin{tabular}{|c|c|c|c|}
\hline Agro ecological zone & Village & Cashew nut count (Nuts/kg) & Water content (\%)c \\
\hline \multicolumn{4}{|l|}{$\mathrm{NG}^{\mathrm{a}}$} \\
\hline & Alafiarou $^{\mathrm{b}}$ & $178.3 \mathrm{ab}$ & $9.2 \mathrm{ab}$ \\
\hline & Bante & $184.7 \mathrm{~b}$ & $10.5 \mathrm{~b}$ \\
\hline & Ina & $179.9 \mathrm{~b}$ & $5.7 \mathrm{a}$ \\
\hline & Kilibo & $160.1 \mathrm{a}$ & $10.8 \mathrm{~b}$ \\
\hline & Tchaourou & $166.4 \mathrm{ab}$ & $8.1 \mathrm{ab}$ \\
\hline & Tchatchou & $169.8 \mathrm{ab}$ & $8.5 \mathrm{ab}$ \\
\hline & Toui & $163.0 \mathrm{ab}$ & $7.4 \mathrm{ab}$ \\
\hline mean & & $171.7 \pm 9.3$ & $8.61 \pm 1.8$ \\
\hline \multicolumn{4}{|l|}{ SS } \\
\hline & Birni & $177.8 \mathrm{ab}$ & $8.5 \mathrm{ab}$ \\
\hline & Chabi-Kouma & $188.6 \mathrm{~b}$ & $9.9 \mathrm{ab}$ \\
\hline & Kolokonde & $179.3 \mathrm{~b}$ & $8.5 \mathrm{ab}$ \\
\hline & Nagayile & $180.5 \mathrm{ab}$ & $7.3 \mathrm{ab}$ \\
\hline & Patargo & $172.8 \mathrm{ab}$ & $10.3 \mathrm{~b}$ \\
\hline & Penessoulou & $165.4 \mathrm{ab}$ & $6.3 \mathrm{a}$ \\
\hline & Pira & $152.5 \mathrm{a}$ & $9.9 \mathrm{ab}$ \\
\hline mean & & $174.8 \pm 11.8$ & $8.68 \pm 1.5$ \\
\hline
\end{tabular}

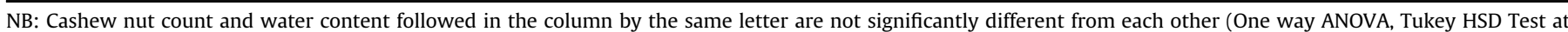
$\mathrm{p} \leq 0.05)$.

$\mathrm{a}=\mathrm{NG}=$ Northern Guinea; SS $=$ Southern Sudanian

b $=$ Number of replication was 10 per village. 
Table 2

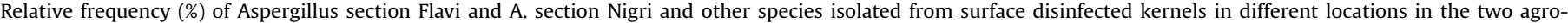
ecological zones of Benin.

\begin{tabular}{|c|c|c|c|c|c|c|c|c|}
\hline Agro-ecological zone ${ }^{a}$ & Location & Contaminated nuts (\%) & Number of strains ${ }^{\mathrm{b}}$ & Flavi $(\%)$ & Nigri (\%) & Eurotium (\%) & Rhizopus (\%) & Mucor (\%) \\
\hline \multirow[t]{7}{*}{ NG } & Alafiarou & 100 & 43 & 2.5 & 92.5 & 40.5 & 2.5 & 0 \\
\hline & Bante & 99.5 & 62 & 20.5 & 96.0 & 56.7 & 5.5 & 1.5 \\
\hline & Ina & 99.5 & 53 & 9.0 & 91.5 & 76.0 & 2.0 & 1.5 \\
\hline & Kilibo & 100 & 55 & 5.0 & 91.5 & 90.0 & 4.0 & 0 \\
\hline & Tchaourou & 100 & 66 & 5.0 & 88.0 & 86.0 & 14.5 & 0.5 \\
\hline & Tchatchou & 100 & 56 & 2.0 & 89.5 & 75.0 & 7.0 & 1.5 \\
\hline & Toui & 100 & 53 & 3.0 & 82.5 & 84.0 & 1.5 & 1.0 \\
\hline \multicolumn{4}{|l|}{ Mean } & 6.7 & 90.2 & & & \\
\hline \multicolumn{4}{|l|}{ Median } & 5.0 & 91.5 & & & \\
\hline \multicolumn{4}{|c|}{ Number of positive/total samples } & $14 / 35$ & $35 / 35$ & & & \\
\hline \multicolumn{4}{|c|}{ Number of positive/total kernels } & $48 / 700$ & $633 / 700$ & & & \\
\hline \multirow[t]{7}{*}{ SS } & Birni & 99.5 & 47 & $0.5 \mathrm{a}$ & $88.7 \mathrm{ab}$ & 47.3 & 4.17 & 0.5 \\
\hline & Chabi-kouma & 100 & 58 & $4.5 \mathrm{~b}$ & $95.5 \mathrm{~b}$ & 33.5 & 5.5 & 0.5 \\
\hline & Kolokonde & 92.5 & 61 & $6.5 \mathrm{~b}$ & $77.0 \mathrm{a}$ & 75.5 & 5.5 & 1.0 \\
\hline & Nagayile & 99.5 & 53 & $3.5 \mathrm{~b}$ & $87.5 \mathrm{ab}$ & 69.3 & 2.5 & 0 \\
\hline & Patargo & 99.5 & 56 & $7.0 \mathrm{~b}$ & $98.5 \mathrm{~b}$ & 62.5 & 1.5 & 0.5 \\
\hline & Penessoulou & 100 & 70 & $9.5 \mathrm{~b}$ & $70.5 \mathrm{a}$ & 94.0 & 11.0 & 2.0 \\
\hline & Pira & 100 & 51 & $0.5 \mathrm{a}$ & $93.0 \mathrm{ab}$ & 96.5 & 0.5 & 0 \\
\hline \multicolumn{4}{|l|}{ Mean } & 4.6 & 87.2 & & & \\
\hline \multicolumn{4}{|l|}{ Median } & 4.5 & 88.9 & & & \\
\hline \multicolumn{4}{|c|}{ Number of positive/total samples } & $17 / 35$ & $35 / 35$ & & & \\
\hline \multicolumn{4}{|c|}{ Number of positive/total kernels } & $34 / 700$ & $637 / 700$ & & & \\
\hline
\end{tabular}

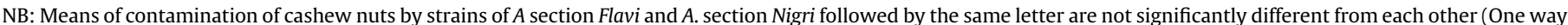
ANOVA, Tukey HSD Test at $\mathrm{p} \leq 0.05$ ).

$\mathrm{a}=\mathrm{NG}=$ Northern Guinea; $\mathrm{SS}=$ Southern Sudanian.

$\mathrm{b}=$ on a total number of 100 kernels plated per village.

Table 3

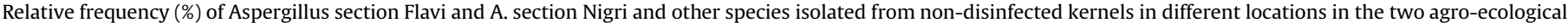
zones of Benin.

\begin{tabular}{|c|c|c|c|c|c|c|c|c|}
\hline Agro-ecological zone $^{a}$ & Location & Contaminated nuts (\%) & Number of strains ${ }^{b}$ & Flavi (\%) & Nigri (\%) & Eurotium (\%) & Rhizopus (\%) & Mucor (\%) \\
\hline \multirow[t]{7}{*}{ NG } & Alafiarou & 100 & 21 & $6.5 \mathrm{ab}$ & 95 & 52.5 & 7.5 & 1.3 \\
\hline & Bante & 100 & 31 & $32.5 \mathrm{~b}$ & 96.30 & 60.0 & 28.8 & 2.5 \\
\hline & Ina & 100 & 22 & $10.0 \mathrm{ab}$ & 98.8 & 62.5 & 10.0 & 0 \\
\hline & Kilibo & 100 & 18 & $10.0 \mathrm{ab}$ & 75 & 92.5 & 0 & 0 \\
\hline & Tchaourou & 100 & 29 & $6.3 \mathrm{ab}$ & 91.3 & 88.8 & 15.0 & 3.8 \\
\hline & Tchatchou & 100 & 26 & $1.3 \mathrm{a}$ & 93.8 & 73.8 & 17.5 & 2.5 \\
\hline & Toui & 100 & 20 & $3.8 \mathrm{a}$ & 78.8 & 91.3 & 1.3 & 0 \\
\hline \multicolumn{4}{|l|}{ Mean } & 10.0 & 89.7 & & & \\
\hline \multicolumn{4}{|l|}{ Median } & 6.5 & 93.8 & & & \\
\hline \multicolumn{4}{|c|}{ Number of positive/total samples } & $11 / 35$ & $35 / 35$ & & & \\
\hline \multicolumn{4}{|c|}{ Number of positive/total kernels } & $30 / 280$ & $253 / 280$ & & & \\
\hline \multirow[t]{7}{*}{ SS } & Birni & 100 & 28 & $25.0 \mathrm{ab}$ & $93.8 \mathrm{ab}$ & 42.5 & 15.0 & 0 \\
\hline & Chabi-kouma & 100 & 28 & $13.8 \mathrm{ab}$ & $93.8 \mathrm{ab}$ & 45.0 & 22.5 & 2.5 \\
\hline & Kolokonde & 100 & 31 & $17.5 \mathrm{ab}$ & $92.5 \mathrm{ab}$ & 41.3 & 3.0 & 1.5 \\
\hline & Nagayile & 100 & 26 & $7.5 \mathrm{ab}$ & $97.5 \mathrm{~b}$ & 58.8 & 12.5 & 1.3 \\
\hline & Patargo & 100 & 22 & $11.3 \mathrm{ab}$ & $100 \mathrm{~b}$ & 67.5 & 1.3 & 0 \\
\hline & Penessoulou & 100 & 33 & $35.0 \mathrm{~b}$ & $83.8 \mathrm{a}$ & 93.8 & 27.50 & 2.5 \\
\hline & Pira & 100 & 21 & $0 \mathrm{a}$ & $92.5 \mathrm{ab}$ & 97.5 & 2.5 & 0 \\
\hline \multicolumn{4}{|l|}{ Mean } & 15.7 & 93.4 & & & \\
\hline \multicolumn{4}{|l|}{ Median } & 13.8 & 93.8 & & & \\
\hline \multicolumn{4}{|c|}{ Number of positive/total samples } & $19 / 35$ & $35 / 35$ & & & \\
\hline \multicolumn{4}{|c|}{ Number of positive/total kernels } & $43 / 280$ & $263 / 280$ & & & \\
\hline
\end{tabular}

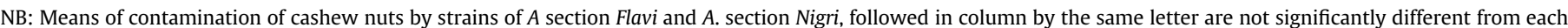
other (One way ANOVA, Tukey HSD Test at $\mathrm{p} \leq 0.05$ ).

$\mathrm{a}=\mathrm{NG}=$ Northern Guinea; $\mathrm{SS}=$ Southern Sudanian

$\mathrm{b}=$ on a total number of 40 kernels plated per village.

whereas LOQ were $0.9,0.7,0.2$ and $1.1 \mu \mathrm{g} / \mathrm{kg}$, respectively. Linearity of the measurements was checked for a standard solution of aflatoxins on spiked matrix. Calibration curves were $\mathrm{y}_{\mathrm{AfB} 1}=2 \mathrm{E}+06 \mathrm{x}+$ 53.437, $\mathrm{yAfB}_{\mathrm{Af}}=335489 \mathrm{x}-31.754, \mathrm{y}_{\mathrm{AfG} 1}=4 \mathrm{E}+06+26.496$ and $\mathrm{y}_{\mathrm{AfG} 2}=745588 \mathrm{x}+24.423$ with correlation coefficients $\left(\mathrm{R}^{2}\right)$ of $0.9993,0.9908,0.9968$ and 0.9994 , respectively.

Among the 84 cashew nut samples analysed, no sample revealed an aflatoxin content above the LOD.

\section{Discussion}

The international trade of cashew nuts is regulated based on several quality parameters including water content, nuts count and aflatoxin content (Cashew handbook, 2014). These parameters give information about the quality of the product. Namdeo, Koulagi, and Wader (2007) concluded that the water in Indian cashew nuts inversely affected the price and the grade, and the higher the number of nuts per kilogram, the poorer their quality. According to 
ACi (2012) the nuts counts are usually in the range of 150-210 nuts/ $\mathrm{kg}$ with 170 nuts/ $\mathrm{kg}$ to 190 nuts/ $\mathrm{kg}$ being nuts of excellent or very good quality, and the recommended water content for storage is $12 \%$ or less. The cashew counts in our study were on average 172 nuts/kg and 174 nuts/kg in NG and SS, respectively. These values agreed with those recently mentioned by Adeniyi and Adedeji (2015) in a similar study in Nigeria.

The average water contents of cashew nuts measured in our study were $8.6 \%$ and 8.7 . These values were below the maximum water level allowed for export, being 12\% (ACi, 2012). Similar studies carried out in Nigeria by Adeniyi and Adedeji (2015) recorded water contents of $7.6 \%$ and $7.4 \%$ in North-Central region. This study area, regarding latitude, is similar to the Northern Guinea and Southern Sudanian regions of Benin, with similar temperature and relative humidity. The water content noticed across both agro-ecological zones can also be explained by the fact that our samples were collected directly from the farmers' storage structure, where harvested cashew nuts might have had time to lose water since harvest.

The recommended harvesting practice for cashew nuts is to collect the nuts when the fruits fall, ensuring that only ripe nuts are collected; but it makes microbial contamination possible via the soil (Cashew Handbook, 2014). Indeed, it is well known that microbial contamination of foodstuffs is mainly via contact during harvesting, with spores present in the soil, but also via insect infestation to damaged or cracked crops, and by crosscontamination during processing (De Saeger, 2011; Lamboni \& Hell, 2009).

In this study, the mycobiota encountered on raw cashew kernels predominantly belonged to the Aspergillus genera, namely Flavi and Nigri groups. The species of these genera are mainly post-harvest fungi reported to be predominant in NG and SS of Benin (Cardwell \& Cotty, 2002). Our results showed that A. section Nigri, Eurotium, A. section Flavi, Rhizopus and Mucor were present on cashew nuts in both zones. Several studies on raw cashew kernels showed similar results. Either at farmer's and retailer's gates (Freire \& Kozakiewicz, 2005) or in storehouses (Adeniyi \& Adedeji, 2015; Gyedu-Akoto, Lowor, Assuah, Kumi, \& Dwomoh, 2014), Aspergillus strains mainly A. niger followed by A. flavus, and Penicillium were predominantly recorded on raw cashew nuts.

Although several strains belonging to A. section Flavi were recorded in our samples, the UHPLC-MS/MS analysis for aflatoxins content revealed that all tested samples were below the detection limit. Indeed, surface contamination with potentially toxigenic fungi does not always mean the presence of mycotoxins. It is well known that fungal growth and toxin production depend on several factors including water activity, temperature, food substrate and strain of the mould (Milhome et al., 2014).

Several studies reported the presence of mycotoxins on nuts and nutty products including almonds and hazelnuts (El tawila et al., 2013), pistachios (Dini, Khazeli, Roohbakhsh, Madadlou, \& Pourenmdari, 2013) and Brazil nuts (Reis et al., 2012) but there are limited studies that investigated the natural occurrence of aflatoxins on raw cashew nuts. Freire et al. (1999) reported that cashew nuts from Brazil were aflatoxin free. In Ghana, Gyedu-Akoto et al. (2014) reported a maximum of $0.09 \mathrm{ppb}$ as total aflatoxins on raw kernels, which is far lower than the $20 \mathrm{ppb}$ limit of Ghana standards authority and the World Health Organisation (WHO), and also the EU limits of $4 \mu \mathrm{g} / \mathrm{kg}$ (European Commission, 2010). Moreover, there were many studies on the occurrence of aflatoxins on processed cashew nuts, but most of them reported also no presence of aflatoxin, or aflatoxins levels lower than the EU limits. Leong, Ismail, Latif, and Ahmad (2010) concluded that cashew nuts purchased from retail outlets in Malaysia were aflatoxins free. Abdulla (2013) and Gyedu-Akoto et al. (2014) reported total aflatoxins concentration to be only $0.185 \mathrm{ppb}$ and $0.3 \mathrm{ppb}$ on roasted kernels from Iraq and Ghana, respectively.

In contrast, there were some reports on the presence of aflatoxins on processed cashew nuts that exceeded the EU limits (Milhome et al., 2014; Acevedo et al., 2011). The presence of aflatoxin on processed nuts could be explained by possible fungi growth during storage or shipment prior to processing.

Thus far, the overall findings presented in this paper show that raw cashew nuts from Benin are within the limits of water content and nuts count for export, and have aflatoxin levels below the limit of detection. The absence of aflatoxin in cashew nut could be explained by its thick shell that is the first barrier for microbial contamination (Lund, Baird-Parker, \& Gould, 2000). Also, cashew nuts are known to contain tannins, which potentially supress aflatoxins formation (Molyneux, Mahoney, Kim, \& Campbell, 2007).

Despite the fact that freshly harvested cashew nuts from Benin seem to be safe with regard to aflatoxins, it is highly and mainly contaminated by strains of $A$. section Nigri from which $A$. niger is known to produce ochratoxin A and fumonisin (Frisvad et al., 2011; Gerez, Dallagnol, Ponsone, Chulze, \& Font de Valdez, 2014; Nielsen, Mogensen, Johansen, Larsen, \& Frisvad, 2009). Due to the high level of contamination by strains of $A$. section Nigri, further investigation will focus on the screening of ochratoxin $A$ and fumonisin in raw nuts. Unfortunately, there is no EU and WHO regulations regarding these mycotoxins, for raw or processed cashew nuts, that could help ranging cashew nuts as good or bad quality. Nevertheless, good agricultural practices need to be strengthened to ensure that the quality is kept constant or improved based on known regulations, namely water content, nuts count and aflatoxin level.

\section{Conclusion}

The occurrence of Aspergillus section Flavi and A. section Nigri was investigated together with the presence of aflatoxins in raw cashew kernels. We conclude that Beninese cashew nuts are contaminated by strains of $A$. section Nigri, while few with strains of A. section Flavi where isolated. The presence of strains from the Flavi group did not result in aflatoxin contamination since samples were below the detection limit. Therefore, based on available regulations on water content, nuts count and aflatoxin level, Beninese cashew nuts were in the range of good quality for export.

\section{Acknowledgments}

The first author (Y. L.) gratefully thanks Wageningen University for financial support, the International Institute of Tropical Agriculture in Benin for support in sampling, and the Department of System Biology of Technical University of Denmark for providing the infrastructure of laboratories for mycological and aflatoxin analyses. We thank Agilent Technologies for the Thought Leader Donation of the UHPLC-MS/MS system.

\section{Appendix A. Supplementary data}

Supplementary data related to this article can be found at http:// dx.doi.org/10.1016/j.lwt.2016.02.017.

\section{References}

Abdulla, N. Q. F. (2013). Evaluation of fungal flora and mycotoxin in some important nut products in Erbil local markets. Research Journal of Environmental and Earth Sciences, 5, 330-336.

Acevedo, A., Smith, J., Ana, Y., \& Villarroel, R. (2011). Incidence of moulds and presence of aflatoxin on toasted cashew nuts (Anacardium occidentale L.) in Venezuela. The Annals of the University Dunarea de Jos of Galati Fascicle VI-Food Technology, 35(2), 9-15. 
ACi. (2010). Analysis of the Benin cashew sector value chain (p. 64). African Cashew Initiative. GTZ.

ACi. (2012). How to estimate the quality of raw cashew nut (RCN)?. Technical manual at http://www.africancashewinitiative.org/imglib/downloads/ACi_GH CASHEW\%20QUALITY 2012.pdf.

Adebajo, L. O., \& Diyaolu, S. A. (2003). Mycology and spoilage of retail cashew nuts. African Journal of Biotechnology, 2(10), 369-373.

Adeniyi, D. O., \& Adedeji, A. R. (2015). Evaluation of fungal flora and mycotoxin potential associated with postharvest handlings of Cashew Nut. Archives of Applied Science Research, 7(2), 30-33.

Cardwell, K. F., \& Cotty, P. J. (2002). Distribution of Aspergillus section Flavi among field soils from the four agroecological zones of the Republic of Bénin, West Africa. Plant Disease, 86, 434-439.

Cashew handbook. (2014). Global perspective. A product of www.cashewinfo.com.

De Saeger, S. (2011). Determining mycotoxins and mycotoxigenic fungi in food and feed (1st ed., p. 456). Woodhead publishing, Technology and Engineering. Online version available at: http://app.knovel.com/hotlink/toc/id:kpDMMFFF02/ determining-mycotoxins/determining-mycotoxins.

Dini, A., Khazeli, P., Roohbakhsh, A., Madadlou, A., \& Pourenmdari, M. (2013). Aflatoxin contamination level in Iran's pistachio nut during years 2009-2011. Food Control, 30, 540-544.

EC (Commission Regulation) No 401/2006 of 23 February (2006). Laying down the methods of sampling and analysis for the official control of the levels of mycotoxins in foodstuffs. Official Journal of the European Union, L 70, 12-34.

El tawila, M. M., Neamatallah, A., \& Serdar, S. A. (2013). Incidence of aflatoxins in commercial nuts in the holy city of Mekkah. Food Control, 29, 121-124.

European Commission. (2010). Guidance document for competent authorities for the control of compliance with EU legislation on aflatoxins. Commission regulation (EC) No. 1152/2009 of 27 November 2009 http://ec.europa.eu/food/food chemicalsafety/contaminants/guidance-2010.pdf.

FAOSTAT. (2015). Food and agriculture organization statistics division. Browsed on February 2015 at http://faostat.fao.org/site/567/DesktopDefault.aspx? PageID $=567$ \#ancor.

Freire, F. C. O., \& Kozakiewicz, Z. (2005). Filamentous fungi, bacteria and yeasts associated with cashew kernels in Brazil. Revista Ciência Agronômica, 36, 249-254.

Freire, F. C. O., Kozakiewicz, Z., \& Paterson, R. R. M. (1999). Mycoflora and mycotoxins of Brazilian cashew kernels. Mycopathologia, 145, 95-103.

Frisvad, J. C., Larsen, T. O., Thrane, U., Meijer, M., Varga, J., Samson, R. A., et al. (2011). Fumonisin and ochratoxin production in industrial Apergillus niger strains. Plos One, 6(8), e23496.

Frisvad, J. C., \& Samson, R. A. (2004). Polyphasic taxonomy of Penicillium subgenus Penicillium. A guide to identification of food and air-borne terverticillate Penicillia and their mycotoxins. Studies in Mycology, 49, 1-174.

Gerez, C. L., Dallagnol, A., Ponsone, L., Chulze, S., \& Font de Valdez, G. (2014). Ochratoxin A production by Aspergillus niger: effect of water activity and a biopreserver formulated with Lactobacillus plantarum CRL 778. Food Control, 45 115-119.

Gyedu-Akoto, E., Lowor, S. T., Assuah, M., Kumi, W., \& Dwomoh, E. A. (2014). Assessment of post-harvest handling effects on quality of cashew nuts and kernels in Ghana. Journal of Scientific Research \& Reports, 3(7), 953-965.

IARC (International Agency for Research on Cancer). (1993). Some naturally occurring substances: food items and constituents, heterocyclic aromatic amines and mycotoxins. IARC monographs on the evaluation of carcinogenic risk to humans, Lyon. IARC, 56, 489-521.

Lamboni, Y., \& Hell, K. (2009). Propagation of mycotoxigenic fungi in maize stores by post-harvest insects. International Journal of Tropical Insect Science, 29(01)
$31-39$.

Lawal, O. W. \& Fagbohun, E. D. (2014). Studies on bio-deterioration, aflatoxin contamination and nutritive values of processed cashew (Anacardium occidentale L) nuts during storage. Nature and Science, 11(9), 127-133.

Leong, Y. H., Ismail, N., Latif, A. A., \& Ahmad, R. (2010). Aflatoxin occurrence in nuts and commercial nutty products in Malaysia. Food Control, 21, 334-338.

Lund, B., Baird-Parker, A. C., \& Gould, G. W. (2000). Microbiological safety and quality of food, 1 p. 2024). Springer US.

Milhome, M. A. L., Lima, C. G., Delima, L. K. Lima, F. A. F. Sousa, D. O. B., \& Nascimento, R. F. (2014). Occurrence of aflatoxins in cashew nuts produced in northeastern Brazil. Food Control, 42, 34-37.

Molyneux, R. J., Mahoney, N., Kim, J. H., \& Campbell, B. C. (2007). Mycotoxins in edible tree nuts. International Journal of Food Microbiology, 119, 72-78.

Namdeo, N. A., Koulagi, K., \& Wader, L. K. (2007). Grade development and study of price-quality relationship of cashew nut in north district of Goa. Agricultural Economics Research Review, 20(1), 171-176.

Nielsen, K. F., Mogensen, J. M., Johansen, M., Larsen, T. O., \& Frisvad, J. C. (2009). Review of secondary metabolite and mycotoxins from the Aspergillus niger group. Analytical and Bioanalytical Chemistry, 395(5), 1225-1242.

Nielsen, K. F. Ngemela, A. F. Jensen, L. B., de Medeiros, L. S., \& Rasmussen, P. H. (2015). UHPLC-MS/MS determination of ochratoxin A and fumonisins in coffee using QuEChERS extraction combined with mixed-mode SPE purification, Journal of Agriculture and Food Chemistry, 63(3), 1029-1034.

Pitt, J. I., \& Hocking, A. D. (1997). Fungi and food spoilage (2nd ed.). London: Blackie Academic Press.

Pitt, J. I., \& Hocking, A. D. (2009). Fungi and food spoilage (3rd ed.). USA: Springer.

Reis, T. A., Oliveira, T. D., Baquião, A. C., Goncalves, S. S., Zorzete, P., \& Corrêa, B. (2012). Mycobiota and mycotoxins in Brazil nut samples from different states of the Brazilian Amazon region. International Journal of Food Microbiology, 159, $61-68$.

Samson, R. A., Hoekstra, E. S., Frisvad, J. C., \& Filtenborg, O. (2002). Introduction to food and airborne fungi. In Centraal Bureau voor Schimmelcultures (6th ed.). The Netherlands: Utrecht.

Samson, R. A., Houbraken, J. A. M. P., Kuijpers, A. F. A., Frank, J. M., \& Frisvad, J. C. (2004). New ochratoxin or sclerotium producing species in Aspergillus section. Nigri. Studies in Mycology, 50, 45-61.

Samson, R. A., Noonim, P., Meijer, M., Houbraken, J., Frisvad, J. C., \& Varga, J. (2007). Diagnostic tools to identify black aspergilli. Studies in Mycology, 59, 129-145.

Samson, R. A., Visagie, C. M., Houbraken, J., Hong, S. B., Hubka, V., Klaassen, C. H. W., et al. (2014). Phylogeny, identification and nomenclature of the genus. Aspergillus. Studies in Mycology, 78, 141-173.

Tolosa, J., Font, G., Manes, J., \& Ferrer, E. (2013). Nuts and dried fruits: natural occurrence of emerging Fusarium mycotoxins. Food Control, 33, 215-220.

UNECE standard DDP-17. (2002). In 2002) New York, \& Geneva (Eds.), Concerning the marketing and the commercial quality control of cashew kernels. United Nations.

Varga, J., Frisvad, J. C., \& Samson, R. A. (2011). Two new aflatoxin producing species and an overview of Aspergillus section. Flavi. Studies in Mycology, 69(1), 57-80.

Wezel, A., Bohlinger, B., \& Bocker, R. (1999). Vegetation zones in Niger and Benin: present and past zonation. In K. Herrmann, K. Vennemann, K. Strahr, \& M. Von Oppen (Eds.), Agricultural Atlas of natural and agronomic resources of Benin and Niger. University of Hohenheim. SFB308. Internet https://www.uni-hohenheim. de/atlas308/a_overview/a3_1/html/english/nframe.htm (Last visited: 14.03.2014)

Whitaker, T. B., Slate, A. B., Doko, B., Maestroni, B., \& Cannavan, A. (2010). Sampling procedures to detect mycotoxins in agricultural commodities. New York, NY, USA: Springer. 